\title{
Molecular Characterization of Antibiotic Resistant Genes among Gram Negative Clinical Isolates
}

\author{
Devasena Umai Ramachandran and Meenambiga Setti Sudharsan* \\ Department of Bio-Engineering, School of Engineering, Vels Institute of Science, Technology and \\ Advanced Studies, Tamil Nadu, India
}

('Corresponding author's e-mail: meenambiga.se@velsuniv.ac.in)

Received: 5 October 2020, Revised: 26 April 2021, Accepted: 5 May 2021

\begin{abstract}
Increasing antibiotic resistance is a threat worldwide. Deep studies have to be done for correct and appropriate usage of antibiotics for treating infections efficiently and to curtail the spread of resistance. Hence, this study is aimed at understanding the prevalence of antibiotic resistance genes among 35 gramnegative bacterial isolates. By performing biochemical tests, the isolates were identified to be Escherichia coli $(\mathrm{n}=15)$, Klebsiella oxytoca $(\mathrm{n}=3)$, Klebsiella pneumoniae $(\mathrm{n}=5)$, Proteus mirabilis $(\mathrm{n}=4)$, Proteus vulgaris $(\mathrm{n}=1)$ and Pseudomonas aeruginosa $(\mathrm{n}=7)$. Antibiotic susceptibility tests showed that most E. coli isolates were resistant to ampicillin, levofloxacin and cefazolin. Ampicillin resistance was found in all of Klebsiella oxytoca, Klebsiella pneumoniae and Proteus mirabilis isolates. All Proteus mirabilis isolates were resistant to ciprofloxacin and co-trimoxazole. Pseudomonas aeruginosa showed maximum resistance to gentamycin and tobramycin. All 35 isolates were sensitive to amikacin, imipenem and meropenem. Polymerase Chain Reaction showed that AmpC and SHV genes were predominant in $E$. coli and Klebsiella species respectively. Among Proteus mirabilis and Pseudomonas aeruginosa, IntI gene was more prevailing. NDM1 gene was not detected in any of the isolates. This study also showed the prevalence of isolates resistant to multiple drugs due to the co-existence of resistant genes. Therefore, control of spread of infections, routine study in this field and proper guidelines for prescribing antibiotics is very necessary.
\end{abstract}

Keywords: Antibiotic resistance, ESBL, MBL, AmpC, Integrons

\section{Introduction}

$20^{\text {th }}$ century was a milestone in the field of medicine as antibiotics were discovered. Until then, even a minor bacterial infection, especially after a successful operation, was enough to kill a person. The discovery of antibiotics opened up a new gate in the field of medicine. The mass production of the antibiotic Penicillin, due to its effectiveness in treating infections, marked the dawn of the great antibiotic era [1]. The period between 1940 and 1960 was the golden age of antibiotics during which several antibiotics, which are used till now, were discovered.

But gradually, bacteria turned out to become resilient towards the antibiotics which were thought to have wholly conquered bacterial infections. Ever since the discovery of the first antibiotic, bacteria have always been looking for ways to act against antibiotics. Right from the 1940s, many strains of bacteria had started becoming resistant to the antibiotics used widely [2]. As predicted by Alexander Fleming, exposure of microbes to non-lethal quantities of antibiotics makes them resistant.

Acquiring resistance mechanisms is a natural process occurring in bacteria. But the factors that speed up the spread of resistance is entirely due to the carelessness and obliviousness of people which include failure to finish the entire course of medicine, self-medication and inappropriate or overuse of antibiotics. These factors result in improper dosage of the drug which will not be enough to kill the bacteria and instead, will make way for bacteria to develop resistance [3]. Over usage of antibiotics is also seen in fishing and agriculture [4]. Drug resistant bacteria can also be spread to humans from livestock or through waste water [5]. A comparative study done to check the prevalence of ESBL producing Escherichia species in livestock and humans showed that livestock animals like cattle were reservoirs of ESBL producing bacteria. Though transmission of these bacteria to humans is possible, the evidence for transmission of these bacteria was very less [6]. 
Bacteria gain resistance by mutations. It can also obtain resistance from the resistant cells in the vicinity. This is possible through transfer of genes through conjugation, transformation, transduction, or by transposons $[7,8]$.

Bacteria confer resistance to antibiotics by modification of a drug target which is due to mutations at the site where the antibiotic targets the bacteria, molecular bypass- a mechanism by which bacteria prevent proper binding of the antibiotic, active efflux or by enzyme-catalyzed inactivation of antibiotics [9-11].

Antibiotic resistance is really a serious issue. Treatment of infections caused by bacteria which are resistant to more than 3 drugs (termed as 'Multi Drug Resistant' bacteria), is very tedious and may involve the use of more than 6 drugs [12]. Some strains are resistant even to the latest generation antibiotics. Doctors find treating these MDR bacterial infections very challenging [13,14]. Drug resistant bacterial infections prolong the time taken for treatment in hospitals [15]. There is significant relationship between drug resistance and mortality [16,17]. A report by WHO confirms that infections due to antibiotic resistant bacteria possess twice the chance of causing death compared to the infections caused by non-resistant bacteria [18]. MDR gram-negative bacteria commonly appear in cases of infections in the urinary tract, skin and blood stream. Multi drug resistance increases the severity in treating people with burns [19,20]. Development of resistance has also complicated urological practices [21]. The most prevalent bacteria in Urinary tract infections are E. coli, Klebsiella species, Proteus species and Pseudomonas species [22]. Though many strains of bacteria have become resistant to almost all beta lactam antibiotics, fosfomycin and nitrofurantoin are still effective in treating urinary tract infections [23]. Thus, MDR gram-negative bacterial infections can be managed by giving antibiotics to which they are susceptible.

The common genes conferring resistance to these bacteria which are reported in many countries are associated with beta lactamase which includes ESBL genes (TEM, SHV), MBL genes (NDM) and AmpC genes [24-26]. Apart from beta lactamase production, bacteria have integrons as another important mechanism that promote the spread of resistance genes from one bacterium to another [27,28]. Integrons are gene capture systems that contain an IntI gene encoding for integrase enzyme which helps in the integration of gene cassette containing resistance genes [29]. Three classes of integrons are commonly associated with resistance. Class 1 is more frequently found. Integrons can also be present in commensal organisms [30].

There is a serious necessity for research in this field to control the factors responsible for the spread of resistance. Also, there is a constant need to study the prevalence of MDR gram-negative bacterial infections in order to bring about effective treatment by giving antibiotics to which they are susceptible. Hence this study is aimed at understanding the diversity of drug resistant gram-negative bacteria isolated from clinical samples obtained from hospitals and laboratories in and around Chennai.

In this study, we have isolated 35 gram-negative bacteria. Biochemical tests were carried out and these bacteria were identified to be of the species Escherichia coli, Klebsiella oxytoca, Klebsiella pneumoniae, Proteus mirabilis, Proteus vulgaris and Pseudomonas aeruginosa. Antibiotic susceptibility tests were done to determine if the organisms were sensitive or resistant to the antibiotics used. Further, the presence of 5 resistance genes (TEM, SHV, NDM, AmpC and IntI) was screened using Polymerase Chain Reaction.

\section{Materials and methods}

\section{Isolation of gram-negative bacteria}

50 bacterial isolates were collected from hospitals and laboratories in and around Chennai during July and August 2019. The isolates derived from clinical samples which included urine, blood and pus alone were included in the collection. The bacteria were cultured by streaking onto Mac Conkey's agar and incubated for $24 \mathrm{~h}$. Then, gram's staining was done to differentiate gram positive and negative bacteria [31]. Bacterial smear was made and it was heat fixed. Crystal violet was added and after 1 min it was washed. Gram's iodine was added and washed after $1 \mathrm{~min}$. Decolorizer was added followed by immediate washing. The smear was covered with safranin and washed after $1 \mathrm{~min}$. Microscopic observation was done. Bacteria which were gram negative were isolated and pure culture was made for those cultures by quadrant streak method.

\section{Catalase test}

A few drops of $\mathrm{H}_{2} \mathrm{O}_{2}$ was taken on a slide. Using a nichrome loop, the test organism was taken and mixed with $\mathrm{H}_{2} \mathrm{O}_{2}$. The slide was observed for the formation of bubbles [32]. 


\section{Oxidase test}

A colony of the test organism was placed on an oxidase disc and was observed for color change. Oxidase positive organisms show a color change to purple color within $10 \mathrm{~s}$. Oxidase negative organisms do not show any color change [32].

\section{Biochemical tests}

The following biochemical tests were performed to identify the isolated bacteria using Bergey's manual $[32,33]$.

\section{Indole test}

Organisms were inoculated in peptone broth. After $24 \mathrm{~h}$ incubation at $37^{\circ} \mathrm{C}$, a few drops of Kovac's reagent were added. The test tube was observed for the appearance of red ring, which indicates the production of indole.

\section{Methyl Red (MR) test}

Organisms were inoculated in MR-VP broth and incubated for $24 \mathrm{~h}$ at $37{ }^{\circ} \mathrm{C}$. A few drops of methyl red indicator were added. Reddish pink color indicates a positive reaction for MR test and a yellow colour indicates negative reaction.

\section{Voges Proskauer (VP) test}

Organisms were inoculated in MR-VP broth. After $24 \mathrm{~h}$ incubation at $37^{\circ} \mathrm{C}$, a few drops of Barrit reagent A followed by Barrit reagent B were added. The color change after $15 \mathrm{~min}$ is observed. Pink color indicates a positive reaction.

\section{Citrate test}

Organisms were streaked onto Simmon's citrate agar and incubated for $24 \mathrm{~h}$ at $37{ }^{\circ} \mathrm{C}$. Blue color indicates a positive reaction and green color indicates a negative reaction.

\section{Urease test}

Urea agar medium was prepared and autoclaved. To $950 \mathrm{~mL}$ of this, $50 \mathrm{~mL}$ of $40 \%$ urea solution was added. The media was dispensed in tubes and allowed to solidify in slanting position and organisms were streaked in this Urea agar. After $24 \mathrm{~h}$ incubation, a color change to pink indicates a positive result.

\section{Triple sugar iron test}

Organisms were inoculated in TSI agar by stabbing onto the butt and streaking on the slant. Color change to yellow (acidic -A), pink (alkaline-K), black $\left(\mathrm{H}_{2 \mathrm{~s}}\right.$ production) and production of gas was observed.

\section{Antibiotic susceptibility test (AST)}

AST was performed for all the 35 samples using Kirby- Bauer disc diffusion technique. It was done according to the guidelines of CLSI [34]. MacFarland (0.5) standard was used to compare the density of inoculum to be used in AST. The organisms were uniformly inoculated onto Muller Hinton Agar and exposed to Antibiotic discs. The plates were incubated for $18 \mathrm{~h}$ at $37{ }^{\circ} \mathrm{C}$. The diameter of zone of inhibition was measured. Amikacin, amoxicillin-clavulanic acid, ampicillin, aztreonam, cefazolin, cefepime, cefotaxime, ceftazidime, cefuroxime, ciprofloxacin, co-trimoxazole, fosfomycin, gentamycin, imipenem, levofloxacin, meropenem, nitrofurantoin, piperacillin-tazobactam and tobramycin were used for isolates of Enterobacteriaceae. For Pseudomonas isolates, amikacin, aztreonam, cefepime, ceftazidime, ciprofloxacin, gentamycin, imipenem, levofloxacin, meropenem, piperacillin-tazobactam and tobramycin were used.

\section{Polymerase chain reaction $(\mathrm{PCR})$ \\ DNA isolation}

$1.5 \mathrm{~mL}$ of bacterial culture was taken in a microfuge tube and centrifuged at 10,000 rpm for $2 \mathrm{~min}$. The pellet was resuspended in digestion buffer and incubated for an hour at $50{ }^{\circ} \mathrm{C}$. To this, equal volume of Phenol-Chloroform-Isoamyl alcohol was added (25:24:1) and centrifuged at 10,000 rpm for $10 \mathrm{~min}$. The top aqueous layer was transferred into fresh tubes and ammonium acetate and ice-cold ethanol were added. It was centrifuged at 5,000 rpm for $5 \mathrm{~min}$. The pellet was washed with $70 \%$ ethanol, air dried and re-suspended in TE buffer [35]. 


\section{PCR}

PCR was carried out for the detection of the 5 genes using primers and cycle conditions described in Table 1 (Agilent technologies) [36-38]. Primers were obtained from Eurofins, Bangalore. After completion of PCR, the PCR products were loaded on $2 \%$ agarose gel. A 1,500 bp DNA marker (Takara) was used for detecting the size of the bands obtained in the gel. Electrophoresis was carried out and Medicare Gelstan UV illuminator was used to document the gel after staining with ethidium bromide.

Table 1 PCR primers and cycle conditions.

\begin{tabular}{|c|c|c|c|}
\hline Primers & Primer sequence & Product size(bp) & Cycle conditions \\
\hline $\begin{array}{l}\text { TEM (F) } \\
\text { TEM (R) }\end{array}$ & $\begin{array}{l}\text { 5'-ATGAGTATTCAACATTTCCG -3' } \\
5^{\prime} \text {-CCAATGCTTAATCAGTGAGG-3' }\end{array}$ & 850 & $\begin{array}{l}\text { Initial denaturation at } 95^{\circ} \mathrm{C} \text { for } 5 \mathrm{~min} \\
35 \text { cycles of: } \\
\text { Denaturation at } 95^{\circ} \mathrm{C} \text { for } 1 \mathrm{~min} \\
\text { Annealing at } 60^{\circ} \mathrm{C} \text { for } 2 \mathrm{~min} \\
\text { Extension at } 72^{\circ} \mathrm{C} \text { for } 1 \mathrm{~min} \\
\text { Final extension at } 72{ }^{\circ} \mathrm{C} \text { for } 10 \mathrm{~min}\end{array}$ \\
\hline
\end{tabular}

Initial denaturation at $95^{\circ} \mathrm{C}$ for $5 \mathrm{~min}$ 35 cycles of:

SHV (F) 5'-TCAGCGAAAAACACCTTG- 3' SHV (R) 5'TCCCGCAGATAAATCACCA-3'

$475 \quad$ Denaturation at $95^{\circ} \mathrm{C}$ for $1 \mathrm{~min}$

Annealing at $60^{\circ} \mathrm{C}$ for $2 \mathrm{~min}$

Extension at $72{ }^{\circ} \mathrm{C}$ for $1 \mathrm{~min}$

Final extension at $72{ }^{\circ} \mathrm{C}$ for $10 \mathrm{~min}$

\begin{tabular}{|c|c|c|c|}
\hline $\begin{array}{l}\operatorname{NDM}(\mathbf{F}) \\
\operatorname{NDM}(\mathbf{R})\end{array}$ & $\begin{array}{l}\text { 5'-GGTTTGGCGATCTGGTTTTC-3' } \\
\text { 5'-CGGAATGGCTCATCACGATC-3', }\end{array}$ & 621 & $\begin{array}{l}\text { Initial denaturation at } 95^{\circ} \mathrm{C} \text { for } 10 \mathrm{~min} \\
35 \text { cycles of: } \\
\text { Denaturation at } 95^{\circ} \mathrm{C} \text { for } 30 \mathrm{~s} \\
\text { Annealing at } 52^{\circ} \mathrm{C} \text { for } 40 \mathrm{~s} \\
\text { Extension at } 72^{\circ} \mathrm{C} \text { for } 50 \mathrm{~s} \\
\text { Final extension at } 72^{\circ} \mathrm{C} \text { for } 10 \mathrm{~min}\end{array}$ \\
\hline $\begin{array}{l}\operatorname{AmpC}(\mathbf{F}) \\
\operatorname{AmpC}(\mathbf{R})\end{array}$ & $\begin{array}{l}\text { 5'-CCCCGCTTATAGAGCAACAA-3' } \\
\text { 5'-TCAATGGTCGACTTCACACC-3' }\end{array}$ & 634 & $\begin{array}{l}\text { Initial denaturation at } 95^{\circ} \mathrm{C} \text { for } 5 \mathrm{~min} \\
35 \text { cycles of: } \\
\text { Denaturation at } 95^{\circ} \mathrm{C} \text { for } 1 \mathrm{~min} \\
\text { Annealing at } 60^{\circ} \mathrm{C} \text { for } 2 \mathrm{~min} \\
\text { Extension at } 72^{\circ} \mathrm{C} \text { for } 1 \mathrm{~min} \\
\text { Final extension at } 72^{\circ} \mathrm{C} \text { for } 10 \mathrm{~min}\end{array}$ \\
\hline $\begin{array}{l}\text { IntI (F) } \\
\text { IntI (R) }\end{array}$ & $\begin{array}{l}\text { 5'-GCCACTGCGCCGTTACCACC-3' } \\
\text { 5'-GGCCGAGCAGATCCTGCACG-3' }\end{array}$ & 898 & $\begin{array}{l}\text { Initial denaturation at } 95^{\circ} \mathrm{C} \text { for } 5 \mathrm{~min} \\
35 \text { cycles of: } \\
\text { Denaturation at } 95^{\circ} \mathrm{C} \text { for } 2 \mathrm{~min} \\
\text { Annealing at } 60^{\circ} \mathrm{C} \text { for } 1 \mathrm{~min} \\
\text { Extension at } 72^{\circ} \mathrm{C} \text { for } 1 \mathrm{~min} \\
\text { Final extension at } 72^{\circ} \mathrm{C} \text { for } 10 \mathrm{~min}\end{array}$ \\
\hline
\end{tabular}

\section{Results and discussion}

Among the 50 isolates collected, there were 35 gram-negative bacteria which originated from urine $(\mathrm{n}=27)$, pus $(\mathrm{n}=5)$ and blood $(\mathrm{n}=3)$ samples. Catalase and oxidase tests were carried out. Catalase positive organisms showed the formation of bubbles and oxidase positive organisms turned purple on the oxidase disc. The number of organisms positive and negative for Gram's staining, catalase tests and oxidase tests are given in Table 2. 
Table 2 Gram's staining, Catalase and Oxidase tests of the clinical isolates.

\begin{tabular}{ccc}
\hline Method & No. of positive isolates & No. of negative isolates \\
\hline Gram's staining & 0 & 35 \\
Catalase test & 35 & 0 \\
Oxidase test & 7 & 28 \\
\hline
\end{tabular}

The isolates were identified using biochemical tests. Out of the 35 isolates, 15 were identified to be E. coli, 3 were Klebsiella oxytoca, 5 were Klebsiella pneumoniae, 4 were Proteus mirabilis, 1 was Proteus vulgaris and 7 were Pseudomonas aeruginosa. The biochemical characterization of the bacteria is given in Table 3.

Table 3 Biochemical characterization of the isolates.

\begin{tabular}{lcccccc}
\hline \multicolumn{1}{c}{ Organisms } & Indole & MR & VP & Citrate & Urease & TSI \\
\hline Escherichia coli $(\mathrm{n}=15)$ & + & + & - & - & - & $\mathrm{A} / \mathrm{A}, \mathrm{Gas}^{+}, \mathrm{H}_{2} \mathrm{~S}-$ \\
Klebsiella oxytoca $(\mathrm{n}=3)$ & + & - & + & + & + & $\mathrm{A} / \mathrm{A}, \mathrm{Gas}^{+}, \mathrm{H}_{2} \mathrm{~S}-$ \\
Klebsiella pneumoniae $(\mathrm{n}=5)$ & - & - & + & + & + & $\mathrm{A} / \mathrm{A}, \mathrm{Gas}^{+}, \mathrm{H}_{2} \mathrm{~S}-$ \\
Proteus mirabilis $(\mathrm{n}=4)$ & - & - & - & + & + & $\mathrm{K} / \mathrm{A}, \mathrm{Gas}^{+}, \mathrm{H}_{2} \mathrm{~S}+$ \\
Proteus vulgaris $(\mathrm{n}=1)$ & + & - & - & + & + & $\mathrm{K} / \mathrm{A}, \mathrm{Gas}^{+}, \mathrm{H}_{2} \mathrm{~S}+$ \\
Pseudomonas aeruginosa $(\mathrm{n}=7)$ & - & - & - & + & - & $\mathrm{K} / \mathrm{K}, \mathrm{Gas}^{-}, \mathrm{H}_{2} \mathrm{~S}_{-}$ \\
\hline
\end{tabular}

$(+)$ indicates positive reaction, $(-)$ indicates negative reaction, $\mathrm{A}$ and $\mathrm{K}$ indicate acidic and alkaline $\mathrm{pH}$ change, respectively.

Antibiotic Susceptibility Test was done for the 35 gram-negative isolates. Percentage of antibiotic resistance for all the 6 species is given in Figure 1. It was seen that $73.33 \%$ of E. coli are resistant to ampicillin and $66.6 \%$ of $E$. coli were resistant to levofloxacin. Cefazolin was resisted by $60 \%$ of $E$. coli, followed by cefotaxime, ceftazidime and cefuroxime each of which were resisted by $46.6 \%$ of $E$. coli isolates. All of Klebsiella oxytoca, Klebsiella pneumoniae and Proteus mirabilis were resistant to ampicillin. Proteus mirabilis also showed $100 \%$ resistance to ciprofloxacin and co-trimoxazole.
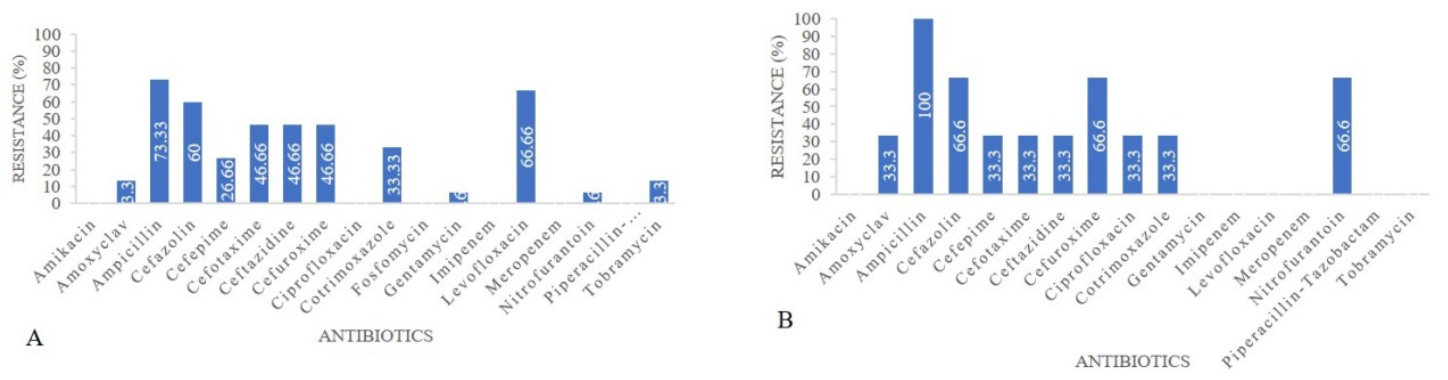

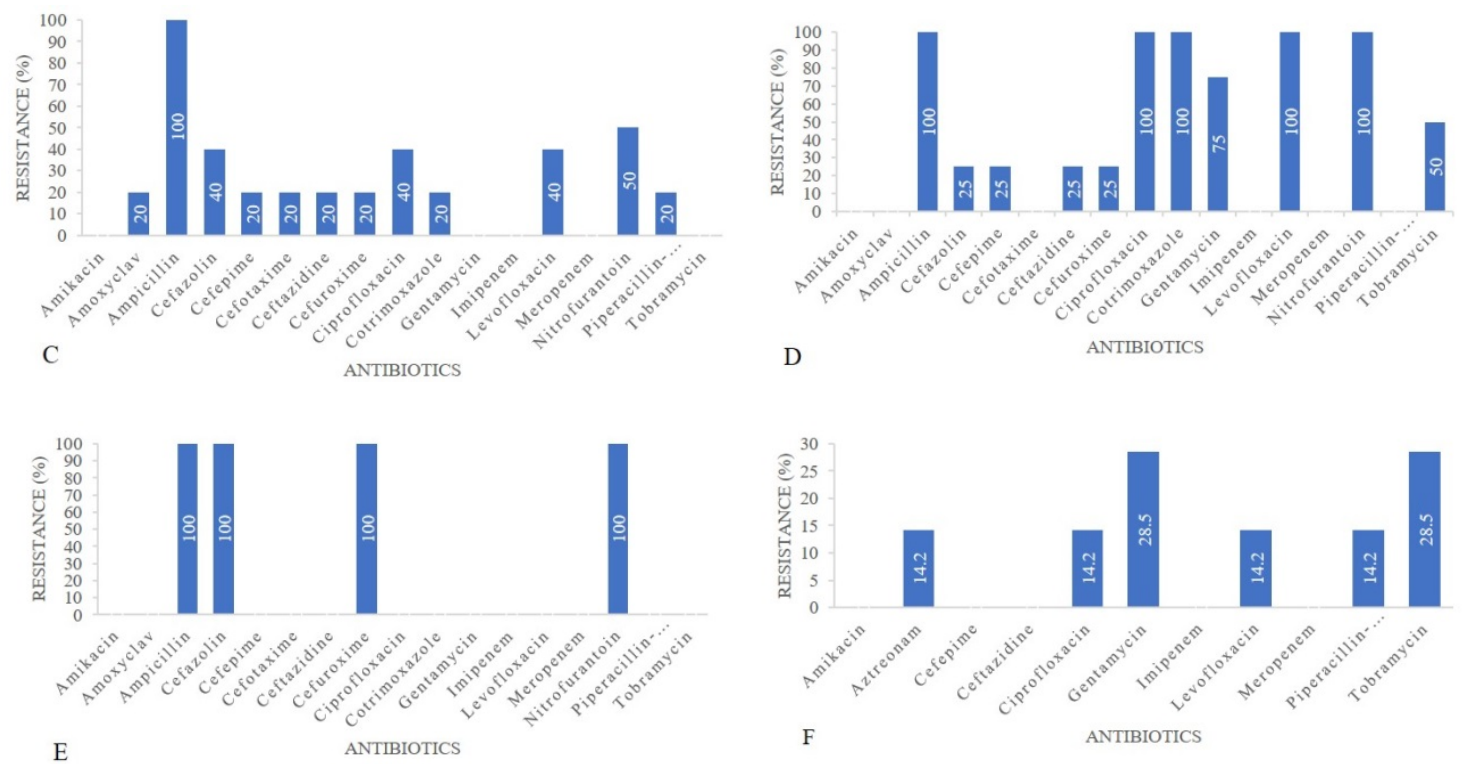

Figure 1 Percentage of antibiotic resistance in A) E. coli, B) Klebsiella oxytoca, C) Klebsiella pneumoniae, D) Proteus mirabilis, E) Proteus vulgaris and F) Pseudomonas aeruginosa.

It is apparent from the antibiotic susceptibility tests that maximum of the isolates is resistant to penicillins, cephalosporins and fluoroquinolones. The data are comparable to a study made in North India, where Klebsiella isolates from a riverine environment showed maximum resistance to ampicillin, cefazolin, cefotaxime and ceftazidime [39]. Another study in North India has shown high resistance of $K$. pneumoniae to aminoglycosides $(77 \%$ ) which is contrary to our study, where all $K$. pneumoniae isolates are sensitive to them [40]. Similar to ours, a study in Iran has reported high resistance of E. coli to cephalosporins and high sensitivity to meropenem and amikacin [41]. Also, in Europe, there has been a noteworthy increase in the resistance of E. coli and Klebsiella spp. towards aminoglycosides, third generation cephalosporins, carbapenems and fluoroquinolones [42].

Hospitalization and increased use of fluroquinolones might probably be the reasons for high resistance to levofloxacin [43]. Since 2000, third generation cephalosporins were prescribed empirically as there was increasing resistance to quinolones and penicillins. Besides, there has been a widespread availability of third generation cephalosporins than narrow spectrum antibiotics. In order to curtail drug resistance, it is necessary that narrow spectrum antibiotics are manufactured and made available commonly and also, they should be used wherever possible instead of broad spectrum antibiotics [44].

Pseudomonas aeruginosa showed maximum resistance to gentamycin (28.5\% isolates) and tobramycin (28.5\% isolates) which are aminoglycosides. However, higher resistance has been reported on aminoglycosides to Pseudomonas aeruginosa in other studies [45,46].

Carbapenem resistance is a growing threat. Treatment of bacterial infections caused by bacteria that are resistant to carbapenems is highly challenging [47]. Interestingly, all our isolates were $100 \%$ sensitive to carbapenems (imipenem and meropenem), unlike several studies reported all over the country $[46,48,49]$. Another study in Tamil Nadu done with E. coli isolates has also showed complete susceptibility to carbapenems [50]. All of those isolates were sensitive to amikacin as well.

PCR was carried out and the 5 genes were visualized using Medicare Gelstan UV illuminator (Figure 2). The distribution of the 5 genes among the 6 species of bacteria isolated is given in Table 4 . 
Table 4 Number of isolates positive for the antibiotic resistant genes.

\begin{tabular}{cccccc}
\hline Organisms & TEM & SHV & NDM & AmpC & IntI \\
\hline Escherichia coli $(\mathrm{n}=15)$ & 5 & 0 & 0 & 13 & 3 \\
Klebsiella oxytoca $(\mathrm{n}=3)$ & 0 & 1 & 0 & 1 & 1 \\
Klebsiella pneumoniae $(\mathrm{n}=5)$ & 0 & 3 & 0 & 2 & 3 \\
Proteus mirabilis $(\mathrm{n}=4)$ & 2 & 0 & 0 & 0 & 0 \\
Proteus vulgaris $(\mathrm{n}=1)$ & 0 & 0 & 0 & 0 & 1 \\
Pseudomonas aeruginosa $(\mathrm{n}=7)$ & 0 & 0 & 0 & 0 & \\
\hline
\end{tabular}
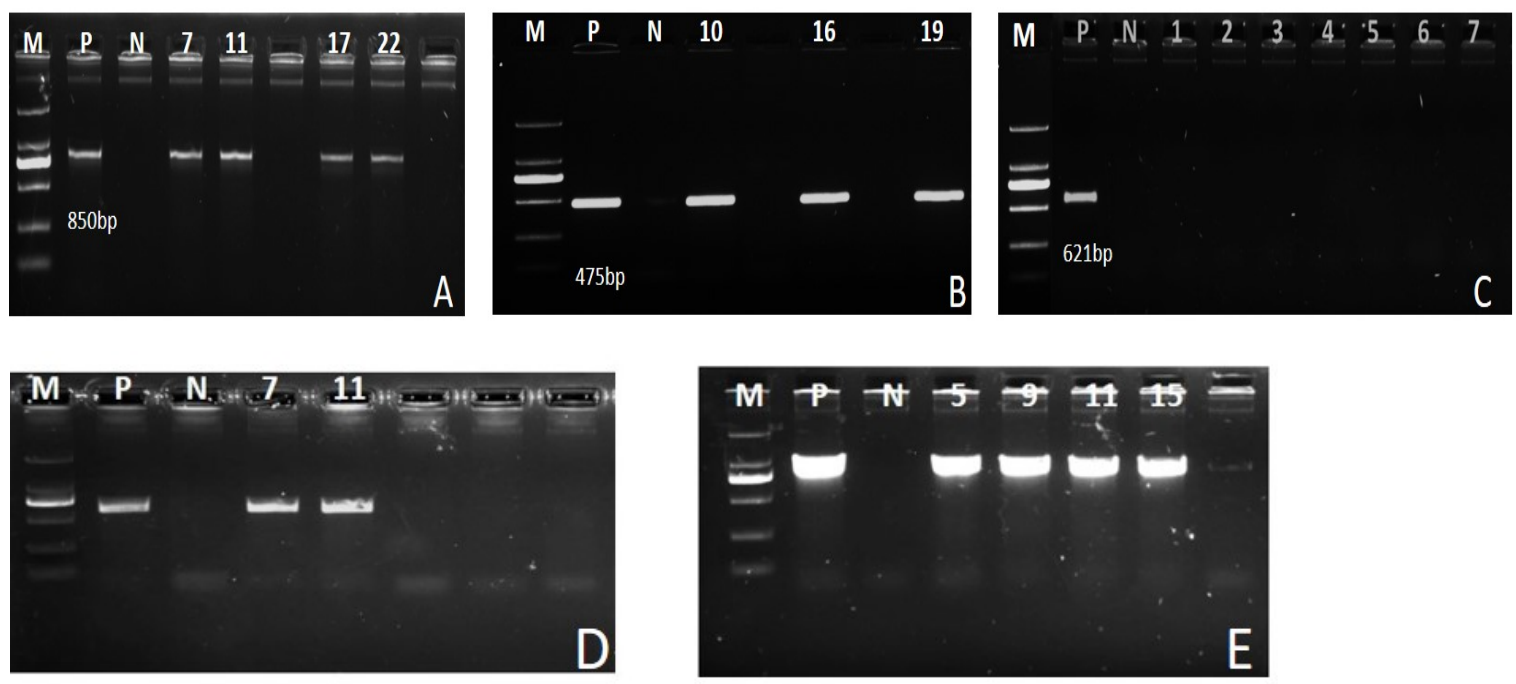

Figure 2 Agarose gel showing some PCR amplified samples of A) TEM gene B) SHV gene C) NDM gene D) AmpC gene and E) IntI gene. (M-Marker, P- Positive control, N-Negative control, Numbers above lanes indicate some of the isolates positive for those genes).

The bacteria which possess genes encoding beta lactamase have the ability to resist beta lactam antibiotics. Beta lactamases are commonly encoded by ESBL genes, MBL genes and AmpC genes [51]. Extended Spectrum Beta Lactamases (ESBL) are enzymes produced by some strains of bacteria that act against beta lactam antibiotics. Extended Spectrum Beta Lactamases are commonly encoded in genes like TEM, SHV and CTX-M. ESBL genes have been reported widely in gram-negative bacteria like E. coli, Klebsiella, Proteus and Pseudomonas spp. [52,53]. Studies show that multi drug resistance is common among bacteria having ESBL genes [54]. Carbapenems are a class of antibiotics for which much resistance is not reported compared to the other classes. Carbapenem resistance is encoded by Metallobeta lactamase genes. AmpC beta lactamases are cephalosporinases. Pseudomonas aeruginosa and E. coli are frequently harbored with AmpC genes [55].

Molecular characterization showed that $86.6 \%$ of E. coli had AmpC gene in them. This was followed by TEM gene (33.3\%) and IntI gene (20\%). $13.3 \%$ of E. coli had both TEM and AmpC genes. All the 3 genes were found in $13.3 \%$ of E. coli. $33.33 \%$ of Klebsiella oxytoca had all $3 \mathrm{SHV}$, AmpC and IntI genes. $60 \%$ of Klebsiella pneumoniae had SHV gene, $40 \%$ had AmpC gene and $20 \%$ had IntI gene. $20 \%$ of Klebsiella pneumoniae had both AmpC and IntI genes. Among Proteus mirabilis, $75 \%$ had IntI gene and $50 \%$ had TEM gene. $50 \%$ of Proteus mirabilis had both IntI and TEM genes. Proteus vulgaris had no resistance genes at all. $14.28 \%$ of Pseudomonas aeruginosa had only IntI gene. 
To summarize, the predominant gene found in the 35 isolates was AmpC (45.71\%). This was followed by ESBL genes, either TEM or SHV (31.2\%). IntI gene was present in $25.7 \%$ of the isolates. The presence of IntI gene (belonging to class 1 integrons) also gives chance for bacteria to develop resistance to various antibiotics as it helps in integrating gene cassettes with resistance genes [29]. 13.3\% of E. coli isolates and $33.33 \%$ of Klebsiella oxytoca had ESBL, AmpC and IntI genes in them. The coexistence of various ESBL genes and AmpC genes is the reason for multi drug resistance of bacteria to many antibiotics like penicillins, cephalosporins and beta lactamase inhibitors [56].

NDM is a frequently reported gene for carbapenem resistance [57]. No isolates were found to have NDM. This is relatable with the $100 \%$ sensitivity to imipenem and meropenem in the AST. As a result, we can conclude that carbapenems could probably be a better drug of choice in this area.

\section{Conclusions}

The prevalence of genes with antibiotic resistance was studied among 35 gram negative clinical isolates and it has been observed that most of the isolates had antibiotic resistance genes with some of them being multi drug resistant. High resistance to penicillin and cephalosporin was observed while there was no resistance to carbapenems by any of the isolates. Bacterial infections are difficult to treat since bacteria have become resistant to almost all the classes of antibiotics that are currently used. The high prevalence of resistance genes is a risk factor which extends the time taken for healing and it may also lead to death in some cases. Thus, there is a serious need for research in the field of drug resistance as this will help us monitor the prevalence of resistant bacteria and thereby improve guidelines in the usage of antibiotics for the treatment of bacterial infections. People should become aware and avoid using antibiotics inappropriately.

\section{Acknowledgements}

The authors are thankful to the Faculty and Management of Vels Institute of Science, Technology, and Advanced Studies for rendering constant support and encouragement and to Optimurz Biosolutions, Chennai for providing necessary facilities to carry out this work.

\section{References}

[1] MI Hutchings, AW Truman and B Wilkinson. Antibiotics: Past, present and future. Curr. Opin. Microbiol. 2019; 51,72-80.

[2] H Landecker. Antibiotic resistance and the biology of history. Body Soc. 2016; 22,19-52.

[3] M Sharma, B Eriksson, G Marrone, S Dhaneria and CS Lundborg. Antibiotic prescribing in two private sector hospitals; one teaching and one non-teaching: A cross-sectional study in Ujjain, India. BMC Infect. Dis. 2012; 12, 155.

[4] SL Gorbach. The need to improve antimicrobial use in agriculture. Clin. Infect. Dis. 2002; 34, S73S144.

[5] IF Jaja, J Oguttu, E Green, V Muchenje. Prevalence and distribution of antimicrobial resistance determinants of Escherichia coli isolates obtained from meat in South Africa. PloS One 2019; 15, e0216914.

[6] C Dahms, NO Hübner, A Kossow, A Mellmann, K Dittmann and A Kramer. Occurrence of ESBLproducing Escherichia coli in livestock and farm workers in Mecklenburg-Western Pomerania, Germany. PloS One 2015; 10, e0143326.

[7] HC Neu. The crisis in antibiotic resistance. Science 1992; 257, 1064-73.

[8] Z Pang, R Raudonis, BR Glick, TJ Lin and Z Cheng. Antibiotic resistance in Pseudomonas aeruginosa: Mechanisms and alternative therapeutic strategies. Biotechnol. Adv. 2019; 37, 177-92.

[9] G Kaufman. Antibiotics: Mode of action and mechanisms of resistance. Nurs. Stand. 2011; 25, 4955.

[10] GD Wright. Molecular mechanisms of antibiotic resistance. Chem. Commun. 2011; 14, 4055-61.

[11] JMA Blair, MA Webber, AJ Baylay, DO Ogbolu and LJV Piddock. Molecular mechanisms of antibiotic resistance. Nat. Rev. Microbiol. 2015; 1, 42-51.

[12] MD Iseman. Treatment of multidrug-resistant tuberculosis. N. Engl. J. Med. 1993; 11, 784-91.

[13] SB Levy and B Marshall. Antibacterial resistance worldwide: Causes, challenges and responses. Nat. Med. 2004; 10, S122-S129. 
[14] M Bassetti, E Righi, A Vena, E Graziano E, A Russo and M Peghin. Risk stratification and treatment of ICU-acquired pneumonia caused by multidrug-resistant/extensively drugresistant/pandrug-resistant bacteria. Curr. Opin. Crit. Care 2018; 24, 385-93.

[15] L Peters, L Olson, DT Khu, S Linnros, NK Le, H Hanberger, NT Hoang, DM Tran and M Larsson. Multiple antibiotic resistance as a risk factor for mortality and prolonged hospital stay: A cohort study among neonatal intensive care patients with hospital-acquired infections caused by gramnegative bacteria in Vietnam. PloS One 2019; 14, e0215666.

[16] S Gandra, KK Tseng, A Arora, B Bhowmik, ML Robinson, B Panigrahi, R Laxminarayan and EY Klein. The mortality burden of multidrug-resistant pathogens in india: A retrospective, observational study. Clin. Infect. Dis. 2019; 69, 563-70.

[17] AS Jarrell, RM Kruer, LD Berescu, PJ Pronovost and JB Trivedi. Factors associated with inhospital mortality among critically ill surgical patients with multidrug-resistant Gram-negative infections. J. Crit. Care 2018; 43, 321-6.

[18] World Health Organization. Antimicrobial resistance: Global report on surveillance. World Health Organization, Geneva, Switzerland, 2014.

[19] AD Khosravi, H Hoveizavi, A Mohammadian, A Farahani and A Jenabi. Genotyping of multidrugresistant strains of Pseudomonas aeruginosa isolated from burn and wound infections by ERICPCR. Acta Cir. Bras. 2016; 31, 206-11.

[20] R Sheridan, J Weber, P Chang, J Schulz, J Goverman, J Friedstat, C Duran, J Benjamin and M Pasternack. Multi-drug resistant gram negative bacteria colonization and infection in burned children: Lessons learned from a 20-year experience. Burns Open 2018; 2, 43-6.

[21] HM Zowawi, PN Harris, MJ Roberts, PA Tambyah, MA Schembri, MD Pezzani, DA Williamson and DL Paterson. The emerging threat of multidrug-resistant Gram-negative bacteria in urology. Nat. Rev. Urol. 2015; 12, 570-84.

[22] M Ali, KA Garba and MS Abdallah. Antibiotic susceptibility profile of bacteria responsible for urinary tract infection (UTI). S. Asian J. Biol. Res. 2018; 1, 12-27.

[23] BJ Gardiner, AJ Stewardson, IJ Abbott and AY Peleg. Nitrofurantoin and fosfomycin for resistant urinary tract infections: Old drugs for emerging problems. Aust. Prescr. 2019; 42, 14-9.

[24] FJ Pérez-Pérez and ND Hanson. Detection of plasmid-mediated AmpC $\beta$-lactamase genes in clinical isolates by using multiplex PCR. J. Clin. Microbiol. 2002; 6, 2153-62.

[25] G Cuzon, T Naas, P Bogaerts, Y Glupczynski and P Nordmann. Evaluation of a DNA microarray for the rapid detection of extended-spectrum $\beta$-lactamases (TEM, SHV and CTX-M), plasmidmediated cephalosporinases (CMY-2-like, DHA, FOX, ACC-1, ACT/MIR and CMY-1-like/MOX) and carbapenemases (KPC, OXA-48, VIM, IMP and NDM). J. Antimicrob. Chemoth. 2012; 8, 1865-9.

[26] T Tada, JI Sekiguchi, S Watanabe, K Kuwahara-Arai, N Mizutani, I Yanagisawa, T Hishinuma, KN Zan, S Mya, HH Tin and T Kirikae. Assessment of a newly developed immunochromatographic assay for NDM-type metallo- $\beta$-lactamase producing Gram-negative pathogens in Myanmar. BMC Infect. Dis. 2019; 19, 565.

[27] PM Bennett. Integrons and gene cassettes: A genetic construction kit for bacteria. J. Antimicrob. Chemoth. 1999; 43, 1-4.

[28] MC Ploy, T Lambert, JP Couty and F Denis. Integrons: An antibiotic resistance gene capture and expression system. Clin. Chem. Lab. Med. 2000; 6, 483-7.

[29] HR Goli, MR Nahaei, MA Rezaee, A Hasani, HS Kafil, M Aghazadeh and V Sheikhalizadeh. Prevalence and molecular characterization of class 1 integrons among clinical isolates of Pseudomonas aeruginosa in Northwest of Iran. Mol. Genet. Microbiol. Virol. 2017; 32, 109-15.

[30] D Skurnik, AL Menac'h, D Zurakowski, D Mazel, P Courvalin, E Denamur, A Andremont and R Ruimy. Integron-associated antibiotic resistance and phylogenetic grouping of Escherichia coli isolates from healthy subjects free of recent antibiotic exposure. Antimicrob. Agents Chemother. 2005; 49, 3062-5.

[31] R Coico. Gram staining. Curr. Protoc. Microbiol. 2006; 1, A.3O.1-A.3O.2.

[32] MP Mishra, NK Debata and RN Padhy. Surveillance of multidrug resistant uropathogenic bacteria in hospitalized patients in Indian. Asian Pac. J. Trop. Biomed. 2013; 3, 315-24.

[33] DH Bergey, FC Harrison, RS Breed, BW Hammer and FM Huntoon. Bergey's manual of determinative bacteriology. The Williams \& Wilkins Co, Maryland. 1923.

[34] Clinical and Laboratory Standards Institute. Performance standards for antimicrobial susceptibility testing. Clinical and Laboratory Standards Institute, Pennsylvania, 2017. 
[35] D Gislin, D Sudarsanam, GA Raj and K Baskar. Antibacterial activity of soil bacteria isolated from Kochi, India and their molecular identification. J. Genet. Eng. Biotechnol. 2018; 16, 287-94.

[36] M Sunde. Prevalence and characterization of class 1 and class 2 integrons in Escherichia coli isolated from meat and meat products of Norwegian origin. J. Antimicrob. Chemoth. 2005; 56, 1019-24.

[37] P Nordmann, T Naas and L Poirel. Global spread of carbapenemase-producing enterobacteriaceae. Emerg. Infect. Dis. 2011; 17, 1791-8.

[38] PS Maneesh, M Sowmiya, T Bharani, HN Madhavan and J Malathi. Characterization of antibiotic resistance profiles of ocular enterobacteriaceae isolates. Eur. J. Microbiol. Immunol. 2016; 6, 40-8.

[39] AH Mondal, MT Siddiqui, I Sultan and QM Haq. Prevalence and diversity of bla TEM, bla SHV and bla CTX-M variants among multidrug resistant Klebsiella spp. from an urban riverine environment in India. Int. J. Environ. Health Res. 2019; 29, 117-29.

[40] N Sharma, AK Gupta, G Walia and R Bakhshi. A retrospective study of the changing trends of antimicrobial resistance of Klebsiella pneumoniae isolated from urine samples over last 3 years (2012-2014). J. Nat. Sci. Biol. Med. 2016; 7, 39-42.

[41] M Baziboroun, M Bayani, Z Poormontaseri, M Shokri, T Biazar. Prevalence and antibiotic susceptibility pattern of extended spectrum beta lactamases producing Escherichia coli isolated from outpatients with Urinary Tract Infections in Babol, Northern of Iran. Curr. Issues Pharm. Med. Sci. 2018; 31, 61-4.

[42] M Exner, S Bhattacharya, B Christiansen, J Gebel, P Goroncy-Bermes, P Hartemann, P Heeg, C Ilschner, A Kramer, E Larson and W Merkens. Antibiotic resistance: What is so special about multidrug-resistant Gram-negative bacteria? GMS Hyg. Infect. Control. 2017; 12, Doc05.

[43] L Johnson, A Sabel, WJ Burman, RM Everhart, M Rome, TD MacKenzie, J Rozwadowski, PS Mehler and CS Price. Emergence of fluoroquinolone resistance in outpatient urinary Escherichia coli isolates. Am. J. Med. 2008; 121, 876-84.

[44] S Gandra, J Joshi, A Trett and L Sankhil. Scoping report on antimicrobial resistance in India. Center for Disease Dynamics Economics \& Policy, Washington, DC, 2017.

[45] P Bhatt, KR Rathi, S Hazra, A Sharma and V Shete. Prevalence of multidrug resistant Pseudomonas aeruginosa infection in burn patients at a tertiary care centre. Indian J. Burns 2015; 23, 56-9.

[46] R Dawra, R Sharma, R Bachhiwal and A Vyas. High incidence of multidrug resistant Pseudomonas aeruginosa isolated from infected burn wounds in a tertiary hospital. Int. J. Curr. Microbiol. Appl. Sci. 2017; 6, 1134-9.

[47] DM Drekonja, SE Beekmann, S Elliott, D Mukundan, H Polenakovik, ME Rosenthal, PD Tamma, PM Polgreen and SJ Weissman. Challenges in the management of infections due to carbapenemresistant enterobacteriaceae. Infect. Control Hosp. Epidemiol. 2014; 35, 437-9.

[48] VN Kulkarni and MV Kulkarni. Trends in antibiotic resistance among major bacterial pathogens isolated from different specimens at a tertiary care hospital in India. J. Adv. Med. Pharm. Sci. 2018; 18, 1-7.

[49] S Verma, SS Thorat, K Bisure. Prevalence of carbapenem resistant enterobacteriaceae: A study in a tertiary care hospital in Mumbai. J. Evolution Med. Dent. Sci. 2018; 7, 4909-12.

[50] XA Marialouis and A Santhanam. Antibiotic resistance, RAPD-PCR typing of multiple drug resistant strains of Escherichia coli from urinary tract infection (UTI). J. Clin. Diagn. Res. 2016; 10, DC05-DC09.

[51] JY Madec, M Haenni, P Nordmann and L Poirel. Extended-spectrum $\beta$-lactamase/AmpC-and carbapenemase-producing Enterobacteriaceae in animals: A threat for humans? Clin. Microbiol. Infect. 2017; 23, 826-33.

[52] G Rajivgandhi, M Maruthupandy, G Ramachandran, M Priyanga and N Manoharan. Detection of ESBL genes from ciprofloxacin resistant Gram negative bacteria isolated from urinary tract infections (UTIs). Front. Lab. Med. 2018; 2, 5-13.

[53] MM Khatun, MM Sharif, AE Haque, S Arifin and KM Ali. Bacteriological profile of ESBL producing bacteria with their antibiotic resistance pattern. KYAMC J. 2019; 10, 7-12.

[54] B Fouzia and AS Damle. Prevalence and characterization of extended spectrum beta-lactamase production in clinical isolates of Klebsiella pneumonia. J. Med. Microb. Diagn. 2015; 4, 182.

[55] R Gupta, A Malik, M Rizvi, M Ahmed and A Singh. Epidemiology of multidrug-resistant Gramnegative pathogens isolated from ventilator-associated pneumonia in ICU patients. J. Glob. Antimicrob. Resist. 2017; 9, 47-50.

[56] VR Gajamer, A Bhattacharjee, D Paul, B Ingti, A Sarkar, J Kapil, AK Singh, N Pradhan and HK Tiwari. High prevalence of carbapenamase genes, AmpC genes and aminoglycoside resistance 
genes in extended spectrum $\beta$-lactamase positive uropathogens from Northern India. J. Glob. Antimicrob. Resist. 2020; 20, 197-203.

[57] Z Cizmeci, E Aktas, B Otlu, O Acikgoz and S Ordekci. Molecular characterization of carbapenemresistant Enterobacteriaceae yields increasing rates of NDM-1 carbapenemases and colistin resistance in an OXA-48-endemic area. J. Chemother. 2017; 29, 344-50. 